\title{
Efficiency Determinant Analysis in Islamic Bank in Indonesia
}

\author{
Abrista Devi, Irman Firmansyah ${ }^{2 *}$ \\ ${ }^{1}$ Fakultas Agama Islam, Universitas Ibn Khaldun, Indonesia \\ ${ }^{2}$ Fakultas Ekonomi dan Bisnis Universitas Siliwangi, Indonesia
}

Submitted: 29 May 2020; Accepted: 10 December 2020; Published: 15 December 2020

\begin{abstract}
This study is aimed to discover efficiency determinant factors of Islamic banks in Indonesia to maintain financial system stability. Financial data of 11 Islamic Banks in Indonesia was obtained from 2010-2019. Purposive sampling method is employed to determine the obtained-sample with the availability of financial statements as criteria. There are two analysis data methods, firstly, Data Envelopment Analysis (DEA) is employed to calculate the efficiency score and analyze the efficiency condition of Islamic banks, and secondly multiple regression analysis which is employed to identify the determinant factors of efficiency. Based on the research model used, this study found that only the CAR and size variables were able to significantly increase the efficiency of Islamic banks. Likewise, macroeconomic variables have not been able to have any impact on the level of efficiency. Policy recommendations are also provided in the end of the discussion chapter.
\end{abstract}

Keywords: data envelopment analysis, efficiency, Islamic bank, macroeconomic variables, microeconomic variables 


\section{INTRODUCTION}

Efficiency is becoming one important indicator for banking sector to contribute to financial system stability of a country. Mirzaei and Moore (2014) explains that industries which heavily rely on finance from bank will grow faster as well as enhanced by the existing of new business in countries with efficient banking systems. Substantially, the study on the bank efficiency will lead to financial system stability has been firstly introduced by King and Levine (1993) in the 1990s. King and Levine (1993) indicated a positive impact banking system development toward Gross Domestic Product (GDP) of a country, productivity, value added of industrial sectors, and sales by micro firms. Another empirical study also conducted by 'Lucchetti, Papi, and Zazzaro, (2001) which assert that bank efficiency has a relationship toward economic growth of a country. Bank also has to achieve microeconomic efficiency (cost and profit efficiency) to optimize the function of banks as intermediary sector, therefore, greater goal to reach sound and proper financial system stability can be realized. Therefore, the study on efficiency and which factors affect to the efficiency also must be continuously conducted. Authors propose a different approach to measure Islamic bank efficiency performance by employing two type of economic-variables, namely micro economic variables (CAR, ROA, NPF, and Size) and macro-economic variables (inflation, exchange rate, BI rate, and GDP).

Currently in Indonesia, there are two types of banking, commercial bank and rural bank. Commercial bank is also divided into two, the bank which is running in conventional mode, and the bank which is running in Islamic teaches. Islamic bank has a prominent contribution toward health financial system of a country. This is because of commercial bank is the most affected bank toward financial stability in many countries (Adami, Gough, Muradoglu, \& Sivaprasad, 2010; Yakubu \& Affoi, 2014). Commercial bank has large asset number and market scope; therefore, all market segments can be reached by commercial bank. In addition, Islamic banks must always maintain their finances in order to remain efficient. Maintaining efficiency condition will help bank management to protect and fix their financial performance, so bank's main goal will be achieved properly.

Ali (2007) comes up with the lesson learned from the banking and crisis in Turkey in 2000 which provides some factors that lead to the closure of Islamic finance in Turkey. Efficiency was one of the factors. Indonesia also experienced the same financial condition. Great financial crisis in 1998 affected most commercial finance, specifically banking sector. Fortunately, Islamic banking was proven more stable than conventional banking in some economic conditions (Beck, Demirgüç-Kunt, \& Merrouche, 2010; Ghassan, Fachin, and Guendouz, 2013). As intermediation system, Islamic bank management is required to alert about their operational banking condition. The entire expenses (cost) arise has to be utilized 
optimally in order to gain maximum return. This condition will represent the bank is able to operate optimally and avoid from the financial loss.

A plethora of previous studies provide some determinant factors which affect bank efficiency. Sufian and Noor (2009) examined the determinant of Islamic bank's efficiency changes in Mena and Asian banking sector. The finding of this paper pointed out that bank efficiency has positive relationship toward banking performance with size, capital, and profitability variables as proxy. Husna and Rahman (2012) through their study show that Islamic banks have relatively more liquid and less risky rather than conventional banks. Study by Ahmad and Noor (2009) and Sugiarto (2003) stated that commercial banks have a positive relationship toward efficiency. CAR and NPF are also the factors that influence the level of efficiency (Wahab, 2015). Permana and Adityawarman (2015) mentioned that ROA has a positive effect on efficiency. Meanwhile, macroeconomic factors also have a relationship with bank performance '(Aviliani, Siregar, Maulana, \& Hasanah, 2015; Combey \& Togbenou, 2017). However, there is still lack of studies which combine two main factors (microeconomic factors and macroeconomic factors) in an empirical model for Islamic banking in Indonesia.

Therefore, in conclusion, this study is not only aimed to determine the level of efficiency of Islamic banks in Indonesia but also to the determinant factors of efficiency from both sides (internal/micro and external/macro factors). One of popular method that can be used to analyze banking efficiency is non-parametric method, namely Data EnvelopmentAnalysis (DEA) (AlDelaimi \& Al-Ani, 2006; Sufian, 2006; Talluri, 2000).

\section{Financial System Stability}

Financial System Stability (read: SSK/Stabilitas Sistem Keuangan) is a condition where financial system is in several situations: (1) facilitating efficient resource allocation regularly from depositors to investors as well as economic resource allocation entirely; (2) able to identify and manage bank's financial risk, (3) able to absorb the fluctuation of economic and financial sector properly (Schinasi, 2006). Financial system stability is a stable financial system that able to allocate fund resources and absorb the existing shocking to avoid real sector and financial system distress. Financial system stability is also defined as financial system resilience toward economic shock, therefore, intermediation function of payment system and risk spread will be run normally (BI, 2007). 


\section{The efficiency with Data Envelopment Analysis (DEA)}

For a business entity, it is important to maintain its financial performance by maintaining a level of efficiency so that it will be stable in carrying out its operations. In general, it does not show the use of resources under the proportions, so that waste will not occur. Therefore, the need for operational costs as an input bank can be appropriate to achieve profit. In the end, the output will be achieved well and show a good level of efficiency. In the bank, Efficiency will show the bank's strength over existing resources to obtain maximum output (Firmansyah, 2018).

Economic theory presents two types of efficiency, namely economic efficiency and technical efficiency (Kalirajan \& Shand, 1999; Yotopoulos \& Lau, 1973). Economic efficiency and technical efficiency have different functions. Generally, technical efficiency is used to assess the performance of a business entity, while economic efficiency is used to view macroeconomic conditions. The technique used to measure the level of efficiency is to compare the input to the output. Data Envelopment Analysis (DEA) is generally used to measure the level of technical efficiency.

Data Envelopment Analysis (DEA) is a linear programming development which is be based on relative performance measurement technique from a group of input and output (Tanjung \& Devi, 2013). DEA analysis method is different from the others because it uses more than one input and output so that it will produce a more comprehensive value.

Relative efficiency of a business unit is an efficiency of a company compared to another company in a group of samples using the same input and output. DEA also can be used to measure efficiency scale. Total technical efficiency is defined as a form of the same proportion enhancement in output. Company achievement is attained by consuming the same quantity of inputs if it is operated by assuming that production limitation form is constant returns to scale (CRS). Pure technical efficiency measurement occurs when output is increasing using technology, or referred as variable return to scale (VRS). Finally, scale efficiency can be calculated as ratio of total technical efficiency (CRS) to pure technical efficiency (VRS). If scale efficiency equal to one (1), then business unit operates with CRS assumption, otherwise characterized with VRS assumption.

\section{METHOD}

Data obtained in this study is the entire Islamic banks in Indonesia that have been publishing (9years) their financial report, as reported from year 2010 to 2019. The sampling method employed in this study is purposive sampling. From 14 registered Islamic banks, only 11 Islamic banks which were providing the financial report in the required period. Those banks are Muamalat, Bank of Syariah Mandiri, Mega Syariah, Panin Syariah, Bukopin Syariah, BJB Syariah, BRI Syariah, BCA Syariah, MayBank Syariah, and Victoria Syariah. 
This study employed quantitative research through secondary data. Secondary data is acquired from several resources, namely: 1) bank internal data which is obtained from each Islamic bank's website, and 2) external data which is acquired from Indonesia's Statistic Centre (read: BPS) and Bank of Indonesia (read: BI).

This study implies two variables, first, dependent variable which is represented by efficiency (EFF), and second, Independent Variables includes capital to adequacy ratio of the bank (CAR), return on asset (ROA), non performing financing (NPF), size of the bank, exchange rate, inflation, gross domestic product (GDP), and BI rate. Following equations are definition and formula of each independent variable:

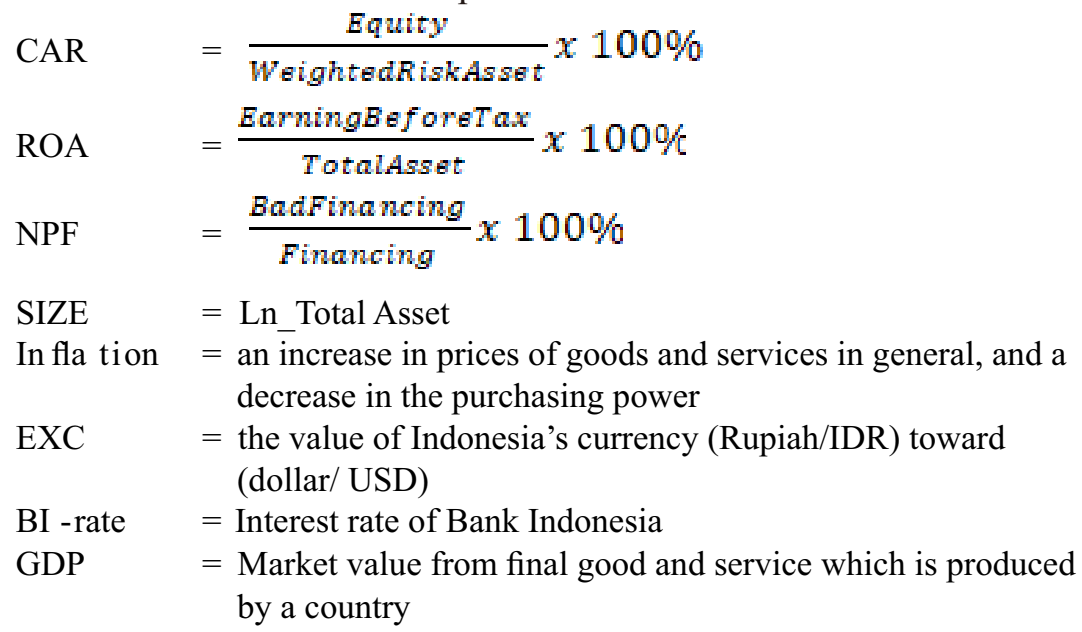

\section{Data Analysis Method}

Data Envelopment Analysis (DEA) will be employed to calculate the score of Islamic bank's efficiency. Charnes, Cooper and Rhodes firstly introduced DEA through constant return to scale (CRS) method. Further, Banker, Charnes and Cooper also contributed to the DEA development through variable return to scale (VRS) method which is finally both methods commonly known as CCR (Charnes-Cooper-Rhodes) and BCC (Banker-Charnes-Cooper) model -(Charnes, Cooper, \& Rhodes, 1978). DEA is formulated to compute the relative efficiency of unit business by optimizing the role of input and output variables. Islamic banks in Indonesia can be considered as unit business, which require the measurement of efficiency as part of its operational evaluation. In order to make calculation in DEA in Islamic bank, we use a number of inputs ( $n$ input) and a number of outputs ( $m$ output). Input and output variables in Islamic bank is determined by using intermediation approach, where we put operational income (Y1) and number of financing as output (Y2), and operational cost (X1), third-party funds (X2), and total asset (X3). Those data will be computed by linier programming technique, where the weighted of total output per total input in periods of time is measured. 
In regard to this, total value of weighted input is restricted equal to 1 for all unit business, while the difference between total output and weighted total input should be less or equal to 0 . This means that all unit business are considered to be below the frontier reference (Tanjung \& Devi, 2013).

In DEA, efficiency score is computed for each period of time in Islamic bank. In this study, there are 11 Islamic bank who published their annual report in vary period (range from 2010-2019). Therefore, the number of observed unit business in this study is about 108 unit business (decision making unit/DMU). Efficiency score of DMU is symbolized by $h_{o}$, where $h_{o}$ is obtained by multiplying the sum of weight of output $r$ and total output $I$ in $s$ period of time.

$$
h_{\circ}=\frac{\sum_{r=1}^{s} u_{r} y_{r o}}{\sum_{i=1}^{m} v_{i} x_{i o}}
$$

Where:

$H_{\bar{o}}=$ bank efficiency $\mathrm{s}, \mathrm{m}=$ number of input, $\mathrm{s}=$ number of output, $\mathrm{y}_{\mathrm{ro}}=$ amount of output $\mathrm{r}$ produced by the DMU, $\mathrm{x}_{\mathrm{io}}=$ amount of input I utilized by the DMU, $\mathrm{u}_{\mathrm{r}}=$ weight of output $r, v_{r}=$ weight of input $i$.

The formulation which is expressed by above equation refers to the use of one input and one output variables. The ratio of efficiency (ho) has to be maximized by restricting to the value of 1 (Avkiran, 2000):

$$
\text { Max } \quad h_{s}=\frac{\sum_{r=1}^{s}{ }^{3}}{\sum_{\mathrm{t}=1}^{m}} \leq 1 ; \mathrm{r}=1, \ldots \ldots, \mathrm{N} .
$$

Subject to

Max $\quad h_{s}=\frac{\sum_{r=1^{8}}^{s}}{\sum_{t=1}^{m}} \leq 1$ for every DMU in the sample, $\mathrm{j}=1, \ldots \ldots, \mathrm{n}$

(number of DMU).

According to the formulation as expressed above, $\mathrm{n}$ denotes the total amount of bank in samples and $r$ denotes the type of sampled-bank. The restriction that is applied to the formulation represents the ratio of efficiency value might be varying, from 0 to 1 . The DMU will be considered as efficient unit only if the efficient ratio value is 1 or $100 \%$. Otherwise, if the efficiency ratio value away from 1 or nearly 0 represents low efficiency of Islamic bank. DEA facilitates each DMU to determine the weight and ensure that the selected weight will derive the best performance measurement. To run the data, Banxia Frontier Analyst 3 software is employed to compute and analyze technical efficiency, overall efficiency, and scale efficiency.

Apart from DEA, multiple regression analysis is employed to analyze the determinant factors of efficiency in Islamic banks, either come from internal factor (such as CAR, ROA, NPF, and SIZE) and external factor/macro factor (Inflation, Exchange Rate, BI rate, Gross Domestic Product). 
The model equation of this study is as follows:

$$
\begin{gathered}
E F F=a+b_{1} C A R+b_{2} R O A+b_{3} N P F+b_{4} S I Z E+b_{5} I N F \\
+b_{6} E X C+b_{7} B I_{\text {rate }}+b_{8} G D P+e
\end{gathered}
$$

Where: EFF denotes efficiency; CAR denotes Capital Adequacy Ratio; ROA denotes Return On Asset; NPF denotes Non Performing Finance; SIZE denotes Ln_Total Asset; INF denotes Inflation; EXC denotes IDR toward US Dollar; BI_rate denotes Interest rate of Bank Indonesia, EFF denotes efficiency, e denotes error.

\section{RESULTS AND DISCUSSION \\ Efficiency Analysis of Islamic Bank}

Figure 2 describes the efficiency trend of Islamic bank in Indonesia. In general, Islamic bank efficiency in Indonesia is showing insignificant fluctuation from year to year either refers to technical efficiency, overall efficiency, and scale efficiency. In 2019, there is a decreasing level of efficiency both scale and overall efficiency, but technically increasing compare to 2018. This decrease could be caused by the increase in assets and third parties owned, but not in proportion to the financing channeled and the income earned. This can be proven from the average liquidity in 2019 , which was $84.16 \%$, an increase from the previous year which was $81.41 \%$. The increase in the ratio shows that the distribution of funds carried out in 2019 was not as good as in 2018 .

In 2016, technical efficiency and overall efficiency reach the optimum level of efficiency; otherwise, the scale efficiency level of Islamic bank tends to decrease in 2016. This condition can be seen from what happened in Islamic bank year 2016 where the market share reached up to $5.3 \%$. This achievement is being one reason where Islamic bank able to reach technical and overall efficiency in 2016. Nonetheless, this condition was causing Islamic bank to add more cost in order to do the business expansion.

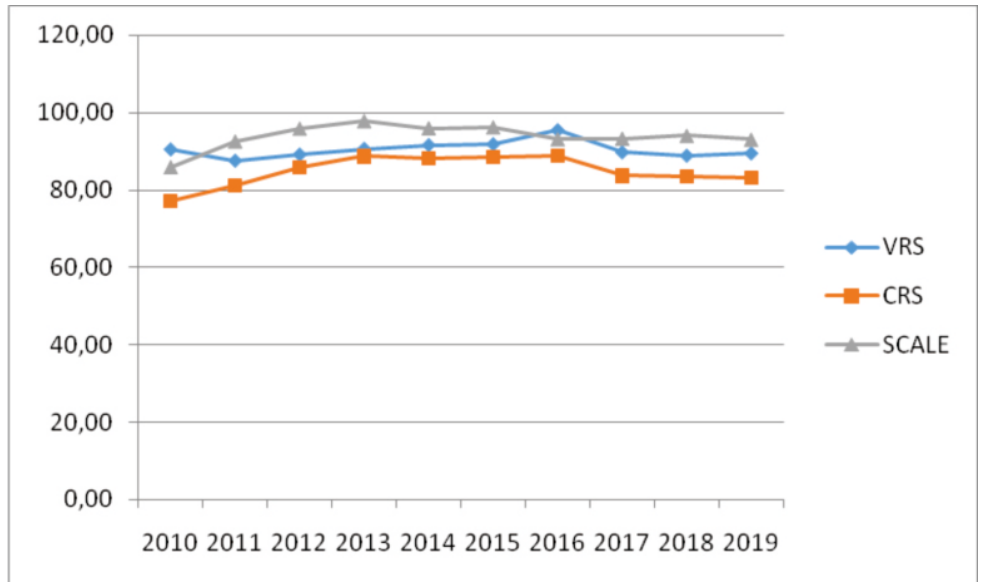

Figure 2: Islamic Bank Efficiency Trend year 2010-2019 
Despite of measuring efficiency of Islamic bank, DEA is also able to measure and ensure whether a Decision-Making Unit (DMU) (determined by banks and time series data obtained) has optimized their production capacity, and how optimal the using of input can generate output. In this case, a DMU will have one of three returns to scale conditions (RTS), there are Increasing Return to Scale (IRS), Constant Return to Scale (CRS), and Decreasing Return to Scale (DRS).

The finding of RTS shows that 44 DMU are in IRS conditions, which means that the current DMU have good performance but could not reach its efficiency. DMU in this condition has an opportunity to increase their potency to optimize output capacity by maintaining existing input, because increasing of input will be ineffective, considering the existing resource has not been optimized yet. There are 33 DMU are in DRS conditions, which means that the current DMU have bad performance but still could reach its optimum efficiency. DMU in this condition is demanded to reduce their input, because the existing number of input and output produced is not ideal, while the rest of 31 DMU are in efficient conditions, which means that the DMU in this condition are in a perfect efficiency condition. The difference level of efficiency among DMUs definitely affected by certain variables and it will be discussed in the next sub chapter.

\section{Direct Effect of Microeconomic and Macroeconomic Variables toward Efficiency of Islamic Bank}

Table 1 provides information about the impact of micro and macroeconomic variables toward efficiency in Islamic bank.

Table 1. Direct Effect of Macro and Microeconomic variables toward Efficiency of Islamic Bank

\begin{tabular}{cccc}
\hline Hypothesis & $\begin{array}{c}\text { Standardized } \\
\text { Loading } \\
\text { Factor }\end{array}$ & t-Value & Conclusion \\
\hline CAR - EFF & 0.23 & 1.97 & Positive - Significant \\
\hline NPF - EFF & 0.11 & 0.70 & Positive - Insignificant \\
\hline ROA - EFF & 0.01 & 0.07 & $\begin{array}{c}\text { Positive } \\
\text { Insignificant }\end{array}$ \\
\hline SIZE - EFF & 0.26 & 2.12 & Positive - Significant \\
\hline BI RATE - EFF & 0.01 & 0.06 & Positive - Insignificant \\
\hline INF - EFF & 0.05 & 0.35 & Positive - Insignificant \\
\hline EXC - EFF & -0.12 & -0.45 & Negative - Insignificant \\
\hline GDP - EFF & -0.14 & -0.51 & Negative - Insignificant \\
\hline Chi - square $=0.01, \mathrm{df}=0$, p-value $=1.00000$, RMSEA $=0.0000$
\end{tabular}

Source: Estimation calculation output using Path Analysis 
The finding of this study indicates that from four (4) macroeconomic variables, none variable has significant effect toward efficiency of Islamic bank. BI rate and inflation show positive effect toward efficiency of Islamic bank, but the effect is insignificant. Meanwhile, exchange rate and GDP show negative effect toward the efficiency of Islamic bank, and again the effect is insignificant.

Islamic bank is using margin and profit sharing in their operational financing activity; nevertheless, it refers to $\mathrm{BI}$ rate to determine the rate of margin and profit sharing. This finding is supported by some studies (Dabla-Noris \& Floerkemeir, 2007), where it is explained that the spread between credit interest rate and deposit is an indicator of financial intermediary institution efficiency. High interest rate spread will indicate inefficiency in banking sector. Therefore, high interest rate spread will reduce potential savers, because of the low of return on deposit and increase the financial cost for borrowers. This condition will affect to the reduction of investment and economic development.

However, the combination of these two groups' independent variables (four microeconomic variables and four macroeconomic variables) show fit model, or in another word the statistical results display satisfying level of goodness of fit. Therefore, macroeconomic variables are factors that should not be worried about which can reduce the efficiency performance of Islamic banks. In line with Altavilla, Boucinha, and Peydro (2017) pointed out that monetary policy (interest rate policy by central bank) is not associated with bank profits in short-term, in particular Islamic banks, which basically do not directly connect interest rates and exchange rates with the profit rate. Empirical studies have also found that macroeconomic variables have no impact on the quality of financing in Islamic banks (Kusmayadi, Firmansyah, \& Badruzaman, 2017).

From four (4) microeconomic variables employed in this study, there are only two variables which have significant effect to the Islamic bank efficiency, namely, CAR and SIZE.

Size has positive and significant effect toward efficiency of Islamic bank. Bank with huge asset generally have sound and supporting infrastructures such as information technology, proper organizational structure, qualified human resource, etc. Those infrastructures obviously built in order to support bank's operational activity '(Widiarti, Siregar, \& Andati, 2015). In addition, bank with huge asset is supported by fully services availability in large region office. Therefore, bank with huge asset could increase their output trough their available resources.

Research by Louati, Louhichi, and Bouljelbene (2016) identify that capital have a positive and significant effect on the insolvency risk of Islamic bank. Adequate capital ratio will help Islamic banks to promote their stability as well as assist the bank to deal with the excessive risk-taking behaviour due to the increasing of bad loan ratios and instability condition. 
In addition, the latest study by Harkati, Alhabshi, and Kassim (2020) support the view that CAR which is determined by Basel III (case in Malaysia) in line with risk-taking behaviour of Islamic bank. On the other word, manager of bank will carefully make a decision under CAR influence. Therefore, bank's managers will try the best to work as efficient as possible.

From the several microeconomic variables which are affecting efficiency of Islamic bank, it can be concluded that size of Islamic bank which is represented by total assert is the highest determinant factor affect to the efficiency of Islamic bank. This means that the optimum use of total asset has a significant role to create wealth for Islamic bank.

\section{CONCLUSION}

According to the discussions, there are some conclusions that can be carried out: Firstly, Islamic bank efficiency in Indonesia is showing insignificant fluctuation from year to year, either refers to technical efficiency, overall efficiency, and scale efficiency. In 2019, scale efficiency and overall efficiency experience to decrease, while technical efficiency displays the decreasing level from previous year. Secondly, according to scale conditions, from 108 observed DMU, 44 DMU are in IRS conditions, 33 DMU are in DRS conditions and 31 DMU are in efficient conditions. DMU in IRS condition denotes that Islamic banks were in good performance but could not reach its efficiency. Meanwhile, DMU in DRS conditions means that Islamic banks perform bad but still have the opportunity to reach its optimum efficiency. DMU in efficient conditions are in perfect efficiency condition. Finally, the finding also shows that Efficiency in Islamic bank is affected positively by CAR and size (Variables from microeconomic aspect). None of macroeconomic variables is empirically proven to have an impact to Islamic bank's efficiency.

As implication of this study, we suggest for Islamic bank practitioners, in particular bank managers to carefully manage their liquidity and asset in order to reach the optimum performance of efficiency. Further, the absence of empirical evidence on the effect of macroeconomic variables on efficiency in Islamic banks shows that efficiency in Islamic banks is more determined by the internal performance of the Islamic bank itself. Considering Islamic banks are usury-free banks, banks distribute their financing based on real sector, therefore the results of this study show that changes in macro indicators do not affect the efficiency of Islamic banks. However, further research is obviously required, why macro variables do not have an impact on the efficiency of Islamic banks, whether it due to regulations or due to their technical operations. 


\section{BIBLIOGRAPHY}

Adami, R., Gough, O., Muradoglu, G., \& Sivaprasad, S. (2010). Returns and Leverage Program. Oxford Business \& Economics Conference. London.

Ahmad, N. H. \& Noor, M. A. N. M. (2011). The Determinants Efficiency and Profitability of World Islamic Banks. 3. Retrieved from International Proceedings of Economics Development and Research, website: www.ipedr.com/vol3/47-M10013.pdf

Al-Delaimi, K. S. K., \& Al-Ani, A. H. B. (2006). Using Data Envelopment Analysis to Measure Cost Efficiency with an Application on Islamic Banks. Scientific Journal of Administrative Development, 4, 134-156.

Ali, S. S. (2007). Financial Distress and Bank Failure: Lessons from Closure of Ihlas Finans in Turkey. Islamic Economic Studies, 4(1).

Altavilla, C., Boucinha, M., \& Peydro, J. L. (2017). Monetary Policy and Bank Profitability in a Low Interest Rate Environment. Working Paper Series 2105. European Central Bank. Aviliani, Siregar, H., Maulana, T. N. A., \& Hasanah, H. (2015). The Impact of Macroeconomic Condition on the Bank's Performance In Indonesia. Buletin Ekonomi Moneter dan Perbankan, 17(4).DOI: https://doi.org/10.21098/bemp.v17i4.503.

Avkiran, N. K. (2000). Decomposing the Technical Efficiency of Trading Banks in the Deregulated Period. The University of Queensland.

Beck, T., Demirgüç-Kunt, A., \& Merrouche, O. (2010). Islamic vs. Conventional Banking: Business Model, Efficiency and Stability. Journal of Banking \& Finance, 37(2), 433447. https://doi.org/10.1016/j.jbankfin.2012.09.016.

BI. (2007). Booklet Stabilitas Sistem Keuangan. Jakarta: Directorate of Research and Regulation of Banking.

Charnes, A., Cooper, W. W., \& Rhodes, E. (1978). Measuring the Efficiency of Decision Making Units. European Journal of Operation Research, 2(6), 429-440.

Combey, A., \& Togbenou, A. (2017). The Bank Sector Performance and Macroeconomics Environment: Empirical Evidence in Togo. International Journal of Economics and Finance, 9(2). DOI:10.5539/ijef.v9n2p180.

Dabla-Noris, E., \& Floerkemeir. (2007). Bank Efficiency and Market Structure: What Determines Banking Spreads in Armenia. International Monetary Fund WP/07/134. Firmansyah, I. (2018). Efficiency and Performance of Islamic Bank: Quadrant Analysis Approach. International Journal of Islamic Business and Economics, 2(1), 15-25. DOI: https://doi.org/10.28918/ijibec.v2i1.1251.

Ghassan, H. B., Fachin, S., \& Guendouz, A. A. (2013). Financial Stability of Islamic and Conventional Banks in Saudi Arabia: A Time Series Analysis. DSS Empirical Economics and Econometrics Working Paper Series No. 2013/1. Sapienza University of Rome. 
Harkati, R., Alhabshi, S. M., \& Kassim, S. (2020). Competition between Conventional and Islamic Banks in Malaysia Revisited. Journal of Islamic Accounting and Business Research.

Husna, H. N., \& Rahman, R. A. (2012). Financial Distress-Detection Model for Islamic Banks. International Journal of Trade, Economics and Finance, 3(3), 158.

Kalirajan, K. P., \& Shand, R. T. (1999). Frontier Production Functions and Technical Efficiency Measures. Journal of Economic Surveys, 13(2), 149-172. https://doi.org/10.1111/1467 -6419.00080 .

King, R. G., \& Levine, R. (1993). Finance and Growth: Schumpeter Might Be Right. The Quarterly Journal of Economics, 108, 717-737., 108, 717-737.

Kusmayadi, D., Firmansyah, I., \& Badruzaman, J. (2017). The Impact of Macroeconomic on Non Performing Loan: Comparison Study at Conventional and Islamic Bank. Iqtishadia, 11(2), 193-216.DOI:10.21043/iqtishadia.v10i2.2864.

Louati, S., Louhichi, A. \& Boujelbene, Y. (2016), "The Risk-Capital-Efficiency Trilogy: A Comparative Study between Islamic and Conventional Banks", Managerial Finance, Vol. 42 No. 12, pp. 1226-1252. DOI 10.1108/MF-01-2016-0009.

Lucchetti, R., Papi, L., \& Zazzaro, A. (2001). Banks' Inefficiency and Economic Growth: A Micro-Macro Approach. Scottish Journal of Political Economy, 48(4), 400-424.

Mirzaei, A., \& Moore, T. (2014). What Are the Driving Forces of Bank Competition Across Different Income Groups of Countries? Journal of International Financial Markets, Institutions and Money, 32(c), 38-71.

Permana, F. Y., \& Adityawarman. (2015). Analisis Faktor-Faktor yang Mempengaruhi Tingkat Efisiensi Perbankan Syariah di Indonesia. Diponegoro Journal of Accounting, 4(3).

Schinasi, G. (2006). Safeguarding of Financial Stability: Theory and Practice. Washington: International Monetary Fund.

Sufian, F. (2006). Size and Return to Scale of the Islamic Banking Industry in Malaysia: Foreign Versus Domestic Banks. IIUM Journal of Economics and Management, 14(2), $147-175$.

Sufian, F., \& Noor, M. A. N. M. (2009). The Determinants of Islamic Banks' Efficiency Changes: Empirical Evidence from the MENA and Asian Countries Islamic Banking Sectors. International Journal of Islamic and Middle Eastern Finance and Management, 2(2), 120-138.

Sugiarto, A. (2003). Mencari Struktur Perbankan yang Ideal. Harian Kompas (16 Juli, 2003).

Talluri, S. (2000). Data Envelopment Analysis: Models and Extensions, Decision Line, 31 (3), 8-11.

Tanjung, H., \& Devi, A. (2013). Metodologi Penelitian Ekonomi Islam. Jakarta: PT Gramata Publishing. 
Wahab. (2015). Analisis Faktor-Faktor Yang Mempengaruhi Efisiensi Bank Umum Syariah di Indonesia Dengan Pendekatan Two Stage Stochastic Frontier Aproach (Studi Analisis di Bank Umum Syariah). Economica, 6(2). DOI : 10.21580/economica.2015.6.2.794.

Widiarti, A. W., Siregar, H., \& Andati, T. (2015). The Determinants of Bank's Efficiency in Indonesia. Buletin of Monetary Economy and Banking, 18(2). DOI: https://doi.org/ 10.21098/ bemp.v18i2.520.

Yakubu, Z., \& Affoi, A. Y. (2014). An Analysis of Commercial Banks' Credit on Economic Growth in Nigeria. Current Research Journal of Economic Theory, 6(2), 11-15.

Yotopoulos, P. A., \& Lau, L. J. (1973). A Test for Relative Economic Efficiency: Some Further Results. The American Economic Review, 63(1), 214-223. 